\section{BAT MORTALITY DUE TO COLLISION WITH WIND TURBINES IN KUTCH DISTRICT, GUJARAT, INDIA}

\author{
S. Ramesh Kumar ${ }^{1}$, A. Mohamed Samsoor Ali $^{2}$ \& P.R. Arun ${ }^{3}$ \\ 1,2,3 Division of Environmental Impact Assessment, Sálim Ali Centre for \\ Ornithology and Natural History (SACON), Anaikatty (PO), Coimbatore, Tamil \\ Nadu 641108, India \\ ${ }^{1}$ ramesh.wild@gmail.com, ${ }^{2}$ amsamsoor@yahoo.co.in (corresponding author), \\ ${ }^{3}$ eiasacon@gmail.com
}

Wind energy production world over has increased dramatically as it is renewable, cost effective and considered environmentally clean mainly because of its role in reducing green-house gases. In India, several wind farms are already working and a few are under construction in areas where wind resource is plentiful. Wind power accounts for $6 \%$ of India's total installed power capacity and it currently generates $1.6 \%$ of the country's power (MNRE 2012). However, the tremendous increase in wind farms (WWEA 2012) has led to negative environmental consequences which include bird and bat mortality and their habitat disturbances (Kunz et al. 2007; Miller 2008; Jain et al. 2011; Camina 2012).

The bat fatalities at wind farms are mostly reported from sub-tropical countries. The first reported mortality of bat species occurred at early generation wind turbines in Australia. Hall \& Richards (1972) reported 22 White-striped Mastiff Bat Tadarida australis mortalities over a four-year study period. The impact of wind energy development on bat species has been known to have increased in recent years, specifically due to large mortalities reported at wind energy developments (Arnett 2006; Jameson \& Wills 2012). Although bats collide with other tall anthropogenic structures such as television towers, communication towers, large buildings, power lines and barbed wire fences, the frequency and number of fatalities is much lower than those observed at wind turbines (Taylor \& Anderson 1973; Crawford \& Baker 1981; Mumford \& Whitaker 1982; Fenton 2001). Some recent studies have reported that bats are killed by wind turbines with far greater frequency relative to other structures (Johnson 2005). Several authors from various parts of the world have discussed the wind farm mortality of bats (Barclay et al. 2007; Miller 2008; Cryan \& Barclay 2009; Graham \& Hudak 2011; Jameson \& Wills 2012). However, despite the large number of wind farms found in India, their impact on birds and bats has been sporadically reported, except for the very recent report of Pande et al. (2013). In this paper we report mortality of bats due to collision with the wind turbines in Kutch District, Gujarat.

Materials and Methods: The study was conducted in a wind farm located at Jangi $\left(23^{0} 15^{\prime} 5.18-23^{0} 11^{\prime} 21.72 \mathrm{~N}\right.$ $\left.\& 70^{0} 30^{\prime} 8.68-70^{\circ} 38^{\prime} 24.68 \mathrm{E}\right)$ about $10 \mathrm{~km}$ to the southeast of Samakhiyali, Bhachau Taluk, Kutch District, Gujarat, India (Fig. 1). The wind turbines were located in agricultural lands, un-irrigated lands and along the coastline. The total land area covered is about 127 acres. The study area is also close to the vast expanse of the Little Rann of Kutch and the Wild Ass Sanctuary, situated its south. The study area has a characteristic dry and hot climate. The hot and humid weather occurs from July to September and cold and dry weather occurs between October and February.

Bird and bat mortality searches were conducted at 51 wind turbines between September 2011 and October 2012. Totally 85 days were spent in the field and 18

DOI: http://dx.doi.org/10.11609/JoTT.o3503.4822-4 | ZooBank: urn:Isid:zoobank.org:pub:810EE124-BB80-486F-9F28-0341A5FAED99

Editor: Sanjay Molur, ZOO/WILD, Coimbatore, India.

Date of publication: 26 September 2013 (online \& print)

Manuscript details: Ms \# 03503 | Received 28 January 2013 | Final received 05 August 2013 | Finally accepted 07 September 2013

Citation: Kumar, S.R., A.M.S. Ali \& P.R. Arun (2013). Bat mortality due to collision with wind turbines in Kutch District, Gujarat, India. Journal of Threatened Taxa 5(13): 4822-4824; http://dx.doi.org/10.11609/JoTT.03503.4822-4

Copyright: (C) Kumar 2013. Creative Commons Attribution 3.0 Unported License. JoTT allows unrestricted use of this article in any medium, reproduction and distribution by providing adequate credit to the authors and the source of publication.

Funding: GP Wind (Jangi) Pvt. Ltd.

Competing Interest: The authors declare no competing interests. Funding sources had no role in study design, data collection, results interpretation and manuscript writing.

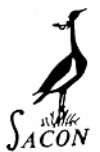

Acknowledgements: We thank the 'Genting Energy Ltd.' for providing fund and other supports. We are grateful to Dr. P.A. Azeezz, Director, Sálim Ali Centre for Ornithology and Natural History for his constant support and encouragements. 


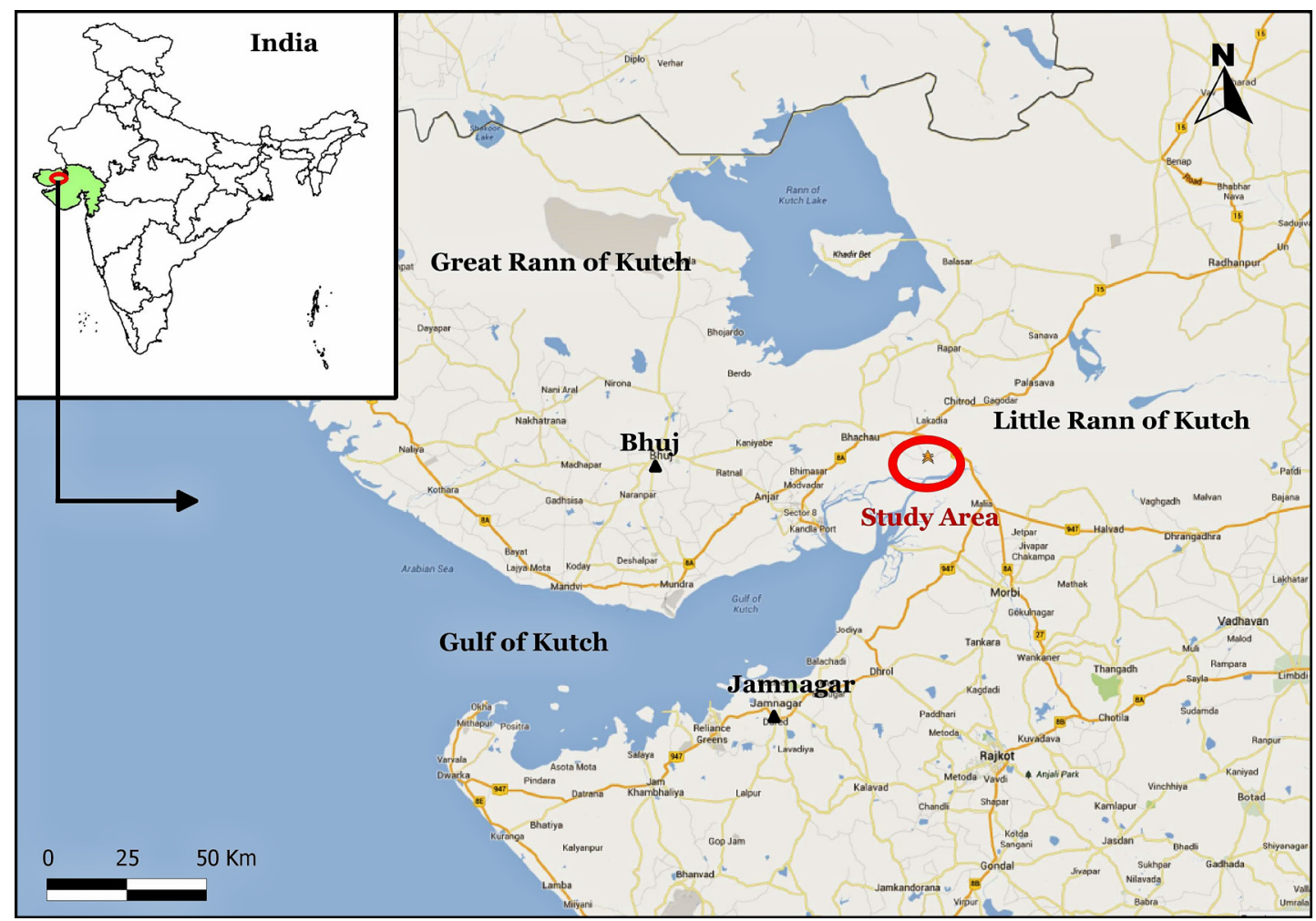

Figure 1. Map of India and Gujarat showing study area

rounds of searches were made around each turbine. The frequency of searches, varied from once a week to once a month. Area under each turbine within $100 \mathrm{~m}$ radius was searched slow walking along spiral path from the base of the turbine outwards. The surrounding habitat of most of the turbines were bare land with small grasses like Dactylactenium sp. and Brachiaria sp. and crop like sorghum so there was no difficulty in locating for the carcasses. The time spent to search each turbine area was approximately 30-45 minutes following Orloff \& Flannery (1992) and Christensen et al. (2003).

Results and Discussion: On 08 October 2012, between 10:00 and 11:00 hr, we recorded two carcasses of bats in two different turbine sites which were $750 \mathrm{~m}$ apart. The size and other morphological characteristics of the bats were noted on the spot and photographs of different views were taken. Later both carcasses of bats were identified as the Greater Mouse-tailed Bat Rhinopoma microphyllum Brunnich, 1782 with the help of Bates \& Harrison (1997).

The first carcass $\left(27^{0} 14^{\prime} 2.90 \mathrm{~N} \& 70^{\circ} 34^{\prime} 2.82 \mathrm{E}\right)$ appeared fresh and was found $3 \mathrm{~m}$ away from the base of the turbine. The left forearm and head were severely injured (Image 1a). Another two to three day old carcass was found $5 \mathrm{~m}$ from the base of another turbine $\left(27^{0} 14^{\prime} 27.31 \mathrm{~N} \& 70^{0} 33^{\prime} 58.79 \mathrm{E}\right)$. Most of the body parts of this specimen had been scavenged by ants (Image 1b), so it was difficult to differentiate external injuries due to collision with the turbine. The Greater Mouse-tailed Bat is not a strong flier and the rapid wing beats are usually interspersed with steady glides and it is primarily insectivorous (Bates \& Harrison 1997). No roosting colony of this species was identified in the study area.

The findings of the present study is the first proof from this area that bats can get affected by the wind turbines. These findings may not be represent of the actual impact potential of wind farms on bats in India but this can be taken as indicative. No significant mortality of bats was recorded from the study area. Based on the reports from some parts of the world it is evident that the mortality of bats due to wind turbines is an emerging threat. The rate is high as 63.9 bats / turbine / year on certain occasions (Fiedler et al. 2007). Only two bat mortalities over a one year study may be due to various factors such as characteristics and location of the wind farms, habitats of the surrounding land, low sampling size, as well as scavengers found in the area.

The potential implications of wind farms for bats are of concern, considering the scale of current applications and the possibility of the effects of multiple wind farms interacting to produce cumulative impacts on 

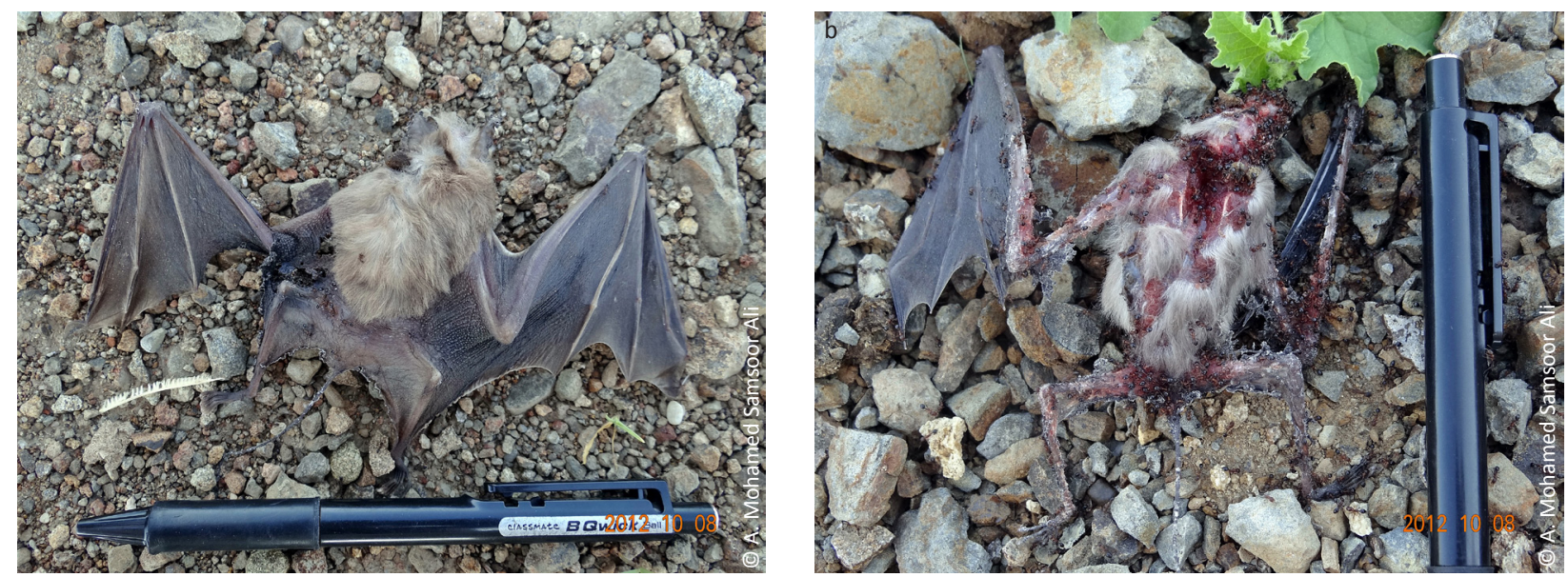

Image 1 (a \& b). Carcasses of Greater Mouse-tailed Bat Rhinopoma microphyllum recorded in two different wind turbines

bat populations. Hence, there is a pressing need for collecting more data on the range of potential impacts of wind farms from across landscapes and seasons to further confirm the findings reported here. There are major gaps in our knowledge with regard to the impact of Indian wind farms on bats. For example, it is not known what is the population size, the diversity or the migration of bats in this region. To what extent each species is prone to wind farm development (from collision and disturbances) is yet to be studied. To understand the actual effect of wind farms on bat populations regular long term monitoring studies are required.

\section{REFERENCES}

Arnett, E.B. (2006). A preliminary evaluation on the use of dogs to recover bat fatalities at wind energy facilities. Wildlife Society Bulletin 34: 1440-1445; http://dx.doi.org/10.2193/00917648(2006)34[1440:APEOTU]2.0.CO;2

Barclay, R.M.R., E.F. Baerwald \& J.C. Gruver (2007). Variation in bat and bird fatalities at wind energy facilities: assessing the effects of rotor size and tower height. Canadian Journal of Zoology 85: 381387; http://dx.doi.org/10.1139/Z07-011

Bates, P.J.J. \& D.L. Harrison (1997). Bats of the Indian Subcontinent Harrison Zoological Museum Press, England.

Camina, A. (2012). Bat fatalities at wind farms in northern Spain lessons to be learned. Acta Chiropterologica 14(1): 205-212; http:// dx.doi.org/10.3161/150811012X654402

Christensen, T.K., I. Clausager \& I.K. Petersen (2003). Base-line investigations of birds in relation to an offshore wind farm at Horns Rev, and results from the year of construction. Report to National Environmental Research Institute. Roskilde, Denmark.

Crawford, R.L. \& W.W. Baker (1981). Bats killed at a north Florida television tower: a 25 year record. Journal of Mammalogy 62: 651652.

Cryan, P.M. \& R.M.R. Barclay (2009). Causes of bat fatalities at wind turbines: hypotheses and predictions. Journal of Mammalogy 90(6): 1330-1340.

Fenton, M.B. (2001). Bats - Revised Edition. Checkmark Books, New York, USA, 224pp.
Fiedler, J.K., T.H. Henry, R.D. Tankersley \& C.P. Nicholson (2007). Results of Bat and Bird Mortality Monitoring at the Expanded Buffalo Mountain Wind farm, 2005. Tennessee Valley Authority, Knoxville, Tennessee, USA.

Graham, T.L. \& P.F. Hudak (2011). Potential hazards of wind energy for rare, threatened, and endangered birds and bats in texas. International Journal of Environmental Research 5(4): 917-922.

Hall, L.S. \& G.C. Richards (1972). Notes on Tadarida australis (Chiroptera: Molossidae). Australian Mammalogy 1: 46.

Jain, A., R.R. Koford, W.A. Hancock \& G.G. Zenner (2011). Bat mortality and activity at a Northern lowa wind resource area. The American Midland Naturalist 165(1):185-200; http://dx.doi. org/10.1674/0003-0031-165.1.185

Jameson, W.J. \& C.K.R. Willis (2012). Bat Mortality at a Wind Power Facility in Central Canada. Northwestern Naturalist 93(3): 194-202; http://dx.doi.org/10.1898/12-03.1

Johnson, G.D. (2005). A review of bat mortality at wind-energy developments in the United States. Bat Research News 46: 45-49.

Kunz, T.H., E.B. Arnett, U. Eden, N.P. Erickson, A.R. Hoar, G.D. Johnson, R.P. Larkin \& M.D. Strickland (2007). Ecological impacts of wind energy development on bats questions, research needs and hypothesis. Frontiers in Ecology and the Environment 5(6): 315-324.

Miller, A. (2008). Patterns of avian and bat mortality at a utility scaled wind farm on the southern high plains. Master Degree Thesis. Texas Tech University.

MNRE (Ministry of New and Renewable Energy, Govt. of India) (2012). Annual Report, 138pp.

Mumford, R.E. \& J.O. Whitaker (1982). Mammals of Indiana. Indiana University Press, Bloomington, 537pp.

Orloff, S. \& A. Flannery (1992). Wind turbine effects on avian activity, habitat use, and mortality in Altamont Pass and Solano County wind resource areas. Work performed by BioSystems Analysis, Inc., Tiburon, CA. Sacramento, CA: California Energy Commission.

Pande, S., A. Padhye, P. Deshpande, A. Ponkshe, P. Pandit, A. Pawashe, S. Pednekar, R. Pandit \& P. Deshpande (2013). Avian collision threat assessment at 'Bhambarwadi Wind Farm Plateau' in northern Western Ghats, India. Journal of Threatened Taxa 5(1): 3504-3515; http://dx.doi.org/10.11609/JoTT.o3096.210

Taylor, W.K. \& B.H. Anderson (1973). Nocturnal migrants killed at a central Florida TV tower: Autumns 1969-1971. Wilson Bulletin 85(1): 42-51.

WWEA (World Wind Energy Association) (2012). World wind energy half yearly report 2012. WWEA Head Office, Bonn, Germany.

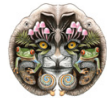

